\title{
Management-Challenged Brazilian Governance and the Low Relevance of National Fishery Management Policy: Recommendations to Promote Viable Small- Scale Fisheries
}

\author{
José Amorim Reis-Filho ${ }^{1,2 *}$ and Antoine OHC Leduc ${ }^{3}$ \\ ${ }^{1}$ Laboratório de Ecologia Bentônica, Universidade Federal da Bahia, Brazil \\ ${ }^{2}$ Instituto de Educação, Ciência e Utilidade Sócio Ambiental (ECUS), Brazil \\ ${ }^{3}$ Instituto de Biologia, Universidade Federal da Bahia, Brazil
}

Submission: March 15, 2017; Published: April 21, 2017

*Corresponding author: José Amorim Reis-Filho, Laboratório de Ecologia Bentônica, Universidade Federal da Bahia, RuaBarão de Geremoabo, s/n. Ondina, Salvador, BA, 40.170-000, Tel: \#5571 999757465; Email: amorim-agua@yahoo.com.br

\begin{abstract}
In a first instance, we approached a view of the Brazilian fishery management underwent political decisions that have modified its organizational administrative structure along last years, for example, no longer consider seasonal fishing closures subsidies to small scale fishers, in part given the current political and economic crisis creating the need to cut down on costs; a decision, that is likely to create further costs, nullifying the savings hoped for. Secondly, we provide suggestions on ways to maintain these subsidies, as to improve the fishery management processes, urging that considering fisheries participants in the political decisions will become essential for sustainable smallscale fisheries.
\end{abstract}

Keywords: Small-scale fisheries; Planned disorganization; Poorly-adapted management; Fishers benefits; Sustainable fishing; Brazil

\section{Introduction}

Fishing is documented as the first activity that prompted humans to organize in settlements, circa 45, 000 y before present. In fact, fishing may precede the agricultural revolution [1], given this livelihood readily provided valuable natural resources with consistency- i.e., fishes and other food of aquatic origin. Despite profound changes in fisheries practices along history (e.g., largescale fishing involving vessels with sophisticated navigation and catch equipment), small-scale fisheries remain responsible for important food supply, with roughly 30 million $t$ of edible fish and shellfish caught worldwide yearly [2].

Globally, adequate management of fishing stocks is one of humanity's most pressing challenges, such that striving to attain sustainable fisheries ever requires insightful knowledge of the drivers that may foster or hinder such state. Nowadays, of the "big barriers"to sustainable fishing [2], the overwhelmingly higher government-subsidized large-scale fisheries may compromise the viability of small-scale fisheries. Indeed, while the large-scale fishery sector may be financially unsustainable without external subsidies [3], this activity sector may be responsible for the depletion many fishing stocks, including 8-20 million $t$ of discarded by catch [4]. Furthermore, many largescale fishing practices may compound these negative impacts by destroying benthic habitat on which many exploited species rely [5]. Thereby, the overall impacts of such financial support in favour of large-scale fisheries are argued to increasingly imperil small-scale fisheries [6]. While fishery policies may sway in the favour of different interests, the admittedly unfair funding model favoring large-scale fisheries may be the result of difficult record-keeping and management of a much larger number of small-scale fishers by government agencies (an issue raised by [2]).

In this opinion note, we aim to underscore how the current Brazilian economical and political contexts might have led to a nation wide 'planned disorganization' of small-scale fishing policies, triggered from poorly-adapted governance regime targeting cost reductions, without any serious considerations 
to potentially interconnected and long-terms negative impacts. Here, we focus on improvements that may be undertaken with regard to managing small-scale fisheries, considering the stakeholders-resource relationship, as this remains fundamental for the advent of feasible and adapted small-scale fisheries governance in Brazil.

Of all the fishing occurring along the extensive Brazilian coastline and hydrographic basins (e.g., the Amazon), 52.5\% of such activity may be considered 'small-scale' and provides a livelihood to an excess of 3 million of individuals [7]. In 2010, of the entire Brazilian gross national product (GNP), the fishing sector accounted for $7 \%$ or US $\$ 34.4$ bi [8]. Given the economical importance of the fishing sector as a whole, the enduring health of small-scale/artisanal fishing is thus of direct relevance for a significant portion of the Brazilian population. Brazilian governmental agencies,such as the Ministries of the Environment and Fisheries are in principle responsible to establish and implement policies aimed at regulating fishing activities for sustainable resource management. Contrastingly to many admittedly detrimental effects to small-scale fisheries in favour of large-scale fisheries (mentioned above), government policies may play central roles in preventing the collapse of fish stocks and their cascading ecological and economic consequences [9-13]. Among various management strategies, the Brazilian governance allocates fishing subsidies during the spawning period of many aquatic species. These subsidies (regionally referred as "segurodefeso") are part of a compensatory measure to individuals classified as 'small-scale fishers', as an incentive to comply with temporary fishing bans (http://www.mpa.gov. br/index.php/pesca/seguro-defeso). Yearly, these subsidies correspond to over 1 billion USD, paid to over 1 million of fishers [8]. This program is congruent with leading scientific propositions, urging that a minimum population sizes survives under a given recruitment regime until conditions of adequate productivity for fishing are re-established [14,15]. As such, fish populations (i.e., stocks) should be maintained to permit their re-growth until the following reproduction period, as to regionally permit sustainable (i.e., long-term) fisheries.

In October 2015, resulting from a political manoeuvre to minimize expenses in an economy in crisis, the federal Brazilian authorities merged the Ministry of Fisheries within the Ministry of the Agriculture. Recently, this latter agency released an inter-ministerial decree $(192 / 2015)$ [16] that terminates the aforementioned subsides to approximately 500.000 of beneficiaries (i.e., fishers and shell fishers) operating in most fishing regions of Brazil, chiefly the Amazon basin and the Northeastern coast, which are amongst the most productive fishing areas of this country [8]. Overall, the decision to suspend this financial compensation isclaimed to be based on a need to reassess the eligibility criterion of beneficiaries and, following Pinheiro et al. [17], hundreds of thousands of fishers may be illegally receiving these benefits, a fact already known to the Brazilian authorities [18]. Consequently, this political manoeuver implies a revision of the criterion enabling individuals to qualify as 'small-scale fishers'. Although these expenses need to be tightly regulated, arguably within any contexts of financial needs (as it may be the case for fishers no-longer compensated during fishing bans), not only the near-term effortsto reduce fishing efforts and promote adequate recruitment will be compromised, but alsopotentially increasingly negative ecological and social effects may arise in the advent these no-payments persist. Thus, this ploy may have potentially important impactsonthe conservation of marine and freshwater biota [17], with lasting repercussions on regional economy and life quality. Few months after (March, 2016), the Supreme Brazilian judicial court revoked the decision to suspend the social benefit, however, all this administrative act has contributed to the slowness of the system that is responsible for the payment of this, thus generating damages to the livelihood of fishers.

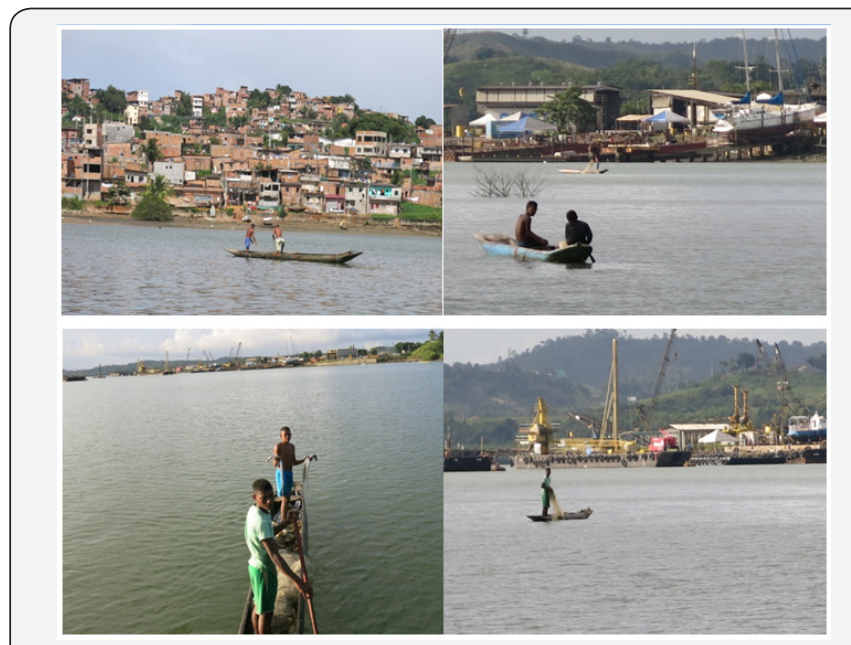

Figure 1: Fishers viewed during its fishery activities and associated to scenarios of urbanization and industrial conflicts.

The advent of this scenario suggests that the medium to longterm environmental, economical and societal consequences were most entirely ignored by the responsible Brazilian conservation and natural resource agencies $[19,20]$. As such, this political manoeuvre adds further concerns to current trends of Brazilian governance on biological conservation by be a decision made solely in an effort to cut short-term expenses. For instance, few more two year ago, the national red lists of endangered species was entirely revoked (released in December 2014) as a result of political influences of the industrial fisheries sector [21]. All this political scenario is extremely worrying because is clear how the little awareness and concern with interests jointing biodiversity and fishers livelihood has been disregarded along modern Brazilian history. As the latest governmental act (13th March, 2017), the Brazilian government in more one administrative act without consider fishers interests, merged the Ministry of Fisheries within the Ministry of the Industry, Foreign trade and Services (9004/2017) [22]. The implications of these political changes to the process of guarantee of fisher's rights in regard to benefits, services and assignments of national 
fishery policy and sovereignty in the fishing areas may became seriously compromised. Yet, a great part of small-scale fisheries contingent remains in an extreme poverty condition as well as further face conflicts with urbanization and industries Figure 1, that besides disputing fisheries territories also have generated habitats destruction/pollution making still more difficult be a fisher in Brazilian waters.

Here, we argue that if indeed reassessing eligibility criterion is required to avoid fraudulent issuance of these subsidies, implementation of these should be maintained and bed is allowed on a case-by-case basis; i.e., in the cases individuals fail to meet qualifying norms. Such strategy would promote both sustainable practices and goodwill among small-scale fisheries participants and governance. Maintaining such financial compensation does not impede recognizing that other measures exist to stimulate sustainability in fisheries (see "the fishery management cycle" in: [2,23] Instead, this involves basing governance choices in favour of conservation strategies that also promote sustainable small-scale fishing livelihoods. While we agree that an adequate policy-based system is required, cooperation with stakeholders, technical agencies and fisheries researchers may be the best alternative to full governmentally-driven policy making [23].

\section{Conclusion}

By the sheer number of involved individuals, small-scale fishery is arguably a challenging endeavour for government management. Despite this reality, practical alternatives exist that may ease government-based practices. Firstly, employing, at least partly, these aforementioned groups of non-government professionals may improve implementing effective monitoring regarding the status of 'small-scale fishers'. Developing regional councils and inter-states commissions (i.e., associated to distinct eco-regions) formed by fishers and fisheries professionals (including governmental agents) could act as effective control for defining and there after identifying small-scale fishers in a cost effective fashion. Furthermore, employing an 'eco-labelling' for consumer-targeted water food products e.g. [2,24] may not only supports small-scale fishers and sustainable fishing initiatives, but provide a direct incentive from within the small-scale fisheries sector for self-monitoring and control. Overall, these approaches may offer regionally-educated knowledge, flexible monitoring methods, along with providing rigorous information required to maintain effective governance measures, such as segurodefeso. Secondly, Ecosystem Approach for Fisheries (EAF) is claimed as an effective alternative to governance and management fishery models [25]. Such approach strives to balance diverse societal objectives by accounting both the knowledge and uncertainties of biotic, abiotic and human components of ecosystems and their interactions, while applying an integrated approach to fisheries within ecologically meaningful boundaries [26]. Currently, EAFis practised in several developed countries, for instance, in the NW Australian shelf $[27,28]$, and the South African pelagic fisheries [29-31]. Such management led to efficient assessment of commercially-exploited stocks, demonstrating the advantages of optimised precautionary resources management. In Brazil, however, implementing these management practices may be initially challenging, mainly given that current management regimes rely on 'conventional' fishery approaches and as such, important updating will be required. As pointed out by Castello [18], the Brazilian fishery management model still rely on academic researchers and government technicians to study aspects of the biology and/or population dynamic of the fishery resources. These groups later passs along this generated knowledge to the management agencies. In principle, these latter agencies will there after determine how to set management models and rules, however in practice this seldom occurs. While this approach has effectively been implemented in the European and North American small-scale fishing models, chiefly given that financial and human resources were at one point provided for reaching intended goals [32], this reality as not yet been envisioned by Brazilian management agencies, and as it stands, no such change, a fishery management model in accordance with sustainable practices won't likely occur in a nearby future.

Here we argue that the creation interdisciplinary panels composed of fishers, governmental agencies representatives, non-government fishing professionals and researches would represent the most comprehensible body able to guide smallscale Brazilian fishery management and to effectively identify 'small-scale fishers' while contributing to maintaining fishing subsidies as an instrument of socio-environmental development. Clearly, under such endeavour transparency would be required (i.e. keeping all processes open and public), including swift communication of findings and results to beneficiaries. Within this context, the small-scale fishing communities may become legitimate, self-guided (i.e., by fishers) organizations, collaborating with other stakeholders to set tangible goals aimed at a desired management objectives. Complementary knowledge and perspective among involved groups may increase the likelihood that economically and ecologically viable smallscale fisheries is attained and maintained in the mid- long-term future. Unless these subsidies are maintained, any benefits (e.g., savings) hoped by Brazilian authorities will likely evaporate when pitted against adverse ecological, social and economic consequences that may ensue from stock depletion. Given the importance of small-scale fisheries in Brazil, the importance of maintaining these resources should be the first interest of governance.

\section{Acknowledgment}

We are grateful to fishers which we live and for sharing their experiences and knowledge with us. The academic debates with Francisco Barros (UFBA), TommasoGiarrizzo (UFPA) and José de Anchieta C.C. Nunes (UFBA) motivated us to prepare this note. J.A.R-F and A.O.H.C.L acknowledge financial support from CAPES (Coordenação de Aperfeiçoamento de Pessoal de Nível Superior). 


\section{Conflict of Interest}

The authors declare that they have no conflict interests.

\section{References}

1. Harari YN (2014) Sapiens: A brief history of Humankind. Harvill Secker, London, UK, pp. 459.

2. Jacquet J, Pauly D (2008) Funding Priorities: Big barries to small-scalle fisheries. Conservation and Policy 22(4): 832-835.

3. Pauly D, Auly D, Christensen V, Guènette S, Pitcher TJ, et al. (2002) Towards sustainability in world fisheries. Nature 418(6898): 689-695.

4. Zeller D, Pauly D (2005) Good news, bad news: global fisheries discards are declining but so are total catches. Fish and Fisheries 6(2): 156-159.

5. Chuenpagdee RL, Morgan E, Maxwell S, Norse EA, Pauly D (2003) Shifting gears: assessing collateral impacts of fishing methods in the U.S. waters. Frontiers in Ecology and the Environment 1(10): 517-524.

6. Ponte S, Raakjaer J, Campling L (2007) Swimming upstream: market access for African fish exports in the context of WTO and EU negotiations and regulation. Development Policy Review 25(1): 113138

7. MPA (2010) Ministério da Pesca e Aquicultura (2010) Boletim Estatístico da Pesca e Aquicultura, Brasil 2008-2009. Brasília, Brazil, pp. 99.

8. MPA (2012) Ministério da Pesca e Aquicultura (2012) Boletim Estatístico da Pesca e Aquicultura, Brasil 2012. Brasília, Brazil, pp. 128.

9. McGoodwin JR (1990) Crisis in the World's Fisheries: People, Problems, and Policies. Stanford University Press, Stanford, California, USA.

10. Caddy JF, Cochrane KL (2001) A review of fisheries management past and present and some future perspectives for the third millennium. Ocean \& Coastal Management 44(9-10): 653-682.

11. Hannesson R (2004) The Privatization of the Oceans. MIT Press, Cambridge, Massachusetts, USA.

12. Bavington D (2009) Managing to endanger: creating a manageable cod fisheries in Newfoundland and Labrador, Maritime Studies, Canada 7(2): 99-121.

13. Johnsen JP (2014) Is fisheries governance possible? Fish and Fisheries 15(3): 428-444.

14. Parma AM (2002) In search of robust harvest rules for Pacific halibut in the face of uncertain assessments and decadal changes in productivity. Bulletin Marine of Science 70(2): 423-453.

15. MacCall AD (2002) Fishery management and stock rebuilding prospects under conditions of low frequency environmental variability and species interactions. Bulletin Marine of Science 70(2): 613-628.

16. Brazil (2015) Ministério da Agricultura. Portaria No. 192/2015 de 05 de Outubro de, Diário Oficial da União- Seção, Brazil 1(6): 194.

17. Pinheiro HT, Di Dario F, Gerhardinger LC, de Melo MR, de Moura RL, et

This work is licensed under Creative

Commons Attribution 4.0 Licens

DOI: 10.19080/OFOAJ.2017.02.555583

al. (2015) Brazilian aquatic biodiversity in peril. Science 350(6264): 1043-1044.

18. Castelo L (2008) Re-pensando o estudo e o manejo da pesca no Brasil. Pan-American Journal of Aquatic Sciences 3(1): 17-22.

19. Vitule JRS, Freire CA, Simberloff D (2009) Introduction of nonnative freshwater fish can certainly be bad. Fish Fish 10(1): 98-108.

20. Pelicice FM, Vitule JRS, Lima-JDP, Orsi ML, Agostinho AA (2014) A serious new threat to Brazilian freshwater ecosystems: The naturalization of nonnative fish by decree. Conservation Letters 7(1): $55-60$.

21. Di Dario F, Alves CBM, Boos H, Frédou FL, Lessa RPT, et al. (2015) A better way forward for Brazil's fisheries. Science 347 (6226): 1079.

22. Brazil (2017) Presidência da República, Casa Civil. Decreto No. 9004/2017 de 13 de Março de, Diário Oficial da União, Brazil.

23. Caddy JF, Seijo JC (2005) This is a more difficult than we thought! The responsibility of scientists, managers and stakeholders to mitigate the unsustainability of marine fisheries. Philos Trans R Soc Lond B Biol Sci 360(1453): 59-75.

24. Bridgespan Group (2005) Seafood choices evaluation. David \& Lucile Packard Foundation, Los Altos, California, USA.

25. Garcia SM, Cochrane KL (2005) Ecosystem approach to fisheries: a review of implementation guidelines. ICES Journal of Marine Science 62: 311-318.

26. FAO (2003) Fisheries management. The ecosystem approach to fisheries. FAO Technical Guidelines for Responsible Fisheries 4 (Suppl 2): 112.

27. Garcia SM, Staples DJ, Chesson J (2000) The FAO guidelines for the development and use of indicators for sustainable development of marine capture fisheries and an Australian example of their application. Ocean and Coastal Management 43(7): 537-556.

28. Fletcher WJ, Chesson J, Fisher M, Sainsbury KJ, Hundloe T, et al. (2002) National ESD Reporting Framework for Australian Fisheries: the "How To" Guide for Wild Capture Fisheries. Fisheries Research and Development Corporation Project 2000/145, Canberra, Australia, pp. 120 .

29. Cochrane KL, Starfield AM (1992) The potential use of predictions of recruitment success in the management of the South African anchovy resource. South African Journal of Marine Science 12(1): 891-902.

30. Cochrane KL, Butterworth DS, de Oliveira JAA, Roel BA (1998) Management procedures in a fishery based on highly variable stocks and with conflicting objectives: experiences in the South African pelagic fishery. Reviews in Fish Biology and Fisheries 8(2): 177-214.

31. De Oliveira JAA, Butterwoth DS (2004) Developing and refining a joint management procedure for the multispecies South African pelagic fishery. ICES Journal of Marine Science 61(8): 1432-1442.

32. Berkes F, Mahon R, McConney P, Pollnac RC, Pomeroy RS (2001) Managing small scale fisheries: alternative directions and methods. International Development Research Centre, Ottawa, Canada, pp. 309.

\begin{tabular}{|l|}
\hline \multicolumn{1}{|c|}{ Your next submission with Juniper Publishers } \\
will reach you the below assets \\
- Quality Editorial service \\
- Swift Peer Review \\
- Reprints availability \\
- E-prints Service \\
- Manuscript Podcast for convenient understanding \\
- Global attainment for your research \\
- Manuscript accessibility in different formats \\
( Pdf, E-pub, Full Text, Audio) \\
- Unceasing customer service \\
Track the below URL for one-step submission \\
https://juniperpublishers.com/online-submission.php \\
\hline
\end{tabular}

